\title{
ATEÍSMO: UM HUMANISMO?
}

Rosalvo Schütz ${ }^{1}$

Resumo: Ateísmo e religião geralmente são considerados alternativas mutuamente excludentes. Crentes acusam ateus de anti-humanistas. Ateus acusam crentes de transferir o humanismo para o além. Pretendemos compreender estas duas posições a partir delas mesmas e evidenciar alguns motivos pelos quais uma percebe a outra como não humanista. Simultaneamente, apontaremos para alguns limites destas posições e procuraremos desvendar a função ideológica da absolutização desta contraposição. Por fim, pretendemos contribuir para a visualização de uma aliança entre ambas numa perspectiva humanista.

Palavras-chave: Religião, Ateísmo, Humanismo.

Abstract: Atheism and religion are generally considered mutually exclusive alternatives. Believers accuse atheists of anti-humanists. Atheists accuse believers of transferring humanism into the beyond. We aim to understand these two positions within themselves and evidence reasons by which one perceives the other as nonhumanist. Simultaneously, we will identify some limits of these positions and try to unravel the ideological function of the absolutization of this counter position. Finally, we intend to contribute to the visualization of an alliance between both in a humanist perspective.

Keywords: Religion, Atheism, Humanism.

\section{Introdução}

Do ponto de vista de alguém crente em Deus, para quem os valores humanos mais profundos e importantes são geralmente atribuídos à origem ou mesmo identidade com valores divinos, o ateísmo inevitavelmente vem associado a um descrédito em relação ao humanismo. Afinal, se os valores de origem divina é que nos fazem realmente humanos, como atribuir o humanismo a alguém ateu? O que restaria a alguém que não crê em valores divinos [que, afinal, possibilitam a orientação da conduta pessoal em valores e parâmetros que transcendem o interesse individual], senão os interesses egoístas e individualistas? Como não levantar suspeita quanto a caráter

\footnotetext{
${ }^{1}$ Professor do Curso de Filosofia e do Programa de Pós-graduação em Filosofia da Universidade Estadual do Oeste do Paraná - UNIOESTE. Doutor em Filosofia pela Uni-Kassel - Alemanha. Bolsista de Produtividade do CNPq. E-mail: rosalvoschutz@ hotmail.com.
} 
humanista do ateu? Pois, segundo o dito popular, "se Deus não existe, tudo é permitido". Não por acaso grande parte dos problemas das sociedades atuais, do ponto de vista crente, são atribuídos a uma "falta de fé em Deus".

Por outro lado, do ponto de vista ateu, para quem os valores atribuídos a Deus pelo crente, são, na verdade, valores humanos, as religiões se apropriam e monopolizam estes valores, de modo a impedir que as pessoas [e as sociedades] se percebam elas próprias como portadoras do humanismo. As religiões seriam, de certa forma, "sequestradoras" dos valores humanistas. A realização do humanismo via religião seria uma realização indireta, possibilitando a instrumentalização do mesmo para fins de dominação e opressão já que, como supostas portadoras dos valores divinos, as religiões se permitem exigências sacrificiais e opressoras sobre as pessoas. Em nome da suposta divindade e do humanismo nelas contidas, a humanidade das pessoas seria negada, tornando-se estas simples joguetes das instituições que se auto-outorgam portadoras desses valores e, consequentemente, de poderes divinos. De modo extremo se poderia afirmar que, enquanto se vive como se houvesse um Deus "manipulando" nosso destino, não poderíamos de fato fazer nossa história e viver a liberdade de forma autêntica. Do ponto de vista ateu, portanto, não é possível ser realmente humanista enquanto se precisa da "desculpa" divina para sê-lo. Só sendo ateu se pode ser humanista de fato.

De modo geral, no tocante às duas posições acima apontadas, opta-se por uma ou outra, de modo que o diálogo entre ateu e crente fica praticamente inviabilizado, uma vez que os pressupostos são, aparentemente, diametralmente opostos e ambos se creem, de fato, portadores do humanismo. No nosso modo de ver, nas duas posições há razões que devem ser levadas a sério e elas contêm também pressupostos autênticos que podem ser explicitados, assim como ambas as posições tem limites e pressupostos ocultos que também devem/podem ser criticamente tematizados. Isto por si só talvez já pudesse/poderá facilitar o estabelecimento de um diálogo produtivo entre ambas as posições. Para além disso, no entanto, nossa hipótese é de que é possível, ao abordar criticamente o próprio conceito de humanismo, ampliar de tal forma o seu significado que tanto religião quanto ateísmo possam ser percebidas como formas de enriquecimento do mesmo. De modo que a oposição entre as duas posições poderá ser superada na medida em que os critérios quanto ao caráter humanista sejam deslocados para outras referências do que aquelas que motivam a atual oposição praticamente irreconciliável entre crença e ateísmo. Por fim, procuraremos realizar um exercício no

\begin{tabular}{|c|c|c|c|c|}
\hline Qevista Dialectus & Ano 2 & n. 4 & Janeiro-Junho 2014 & p. $127-149$ \\
\hline
\end{tabular}


sentido de visualizar a possibilidade de uma aliança destas duas posições numa perspectiva humanista com o apoio da teoria de Ernst Bloch.

Passemos, portanto, apoiados em alguns autores de história da filosofia, a tematizar as duas posições primeiramente indicadas e a construir a possibilidade de uma nova, para além do dualismo maniqueísta preponderante.

\section{Ateísmo como negação do humanismo}

A desconfiança suscitada desde a perspectiva religiosa em relação ao ateu, acima apontada, se justifica, em grande medida, pelo fato de aquele crer que a religião é depositárias dos valores humanos que tornam possível a convivência humana. Esses valores, portanto, seriam negados por aqueles que pretendem sobrepor seus interesses individuais e egoístas aos outros. Ou seja, a negação de Deus (e de tudo o que este representa) é, para o crente, um artifício usado por aqueles que não pretendem se comprometer com valores e perspectivas humanistas que ultrapassem os seus interesses individuais. A expressão popular de que o "ateu é à toa" traduz algo desta perspectiva: alguém ateu é alguém que supostamente não tem parâmetros de orientação de suas ações, e, por isso, dificilmente poderia ter um sentido significativo em sua vida e, por conseguinte, dificilmente se comprometeria com perspectivas humanizadoras e emancipatórias, tornando-se uma vítima fácil dos apelos e tendências individualistas que facilmente podem levar a vida humana a uma situação catastrófica. Não seria nem mesmo possível confiar ou estabelecer relações de confiança com um ateu, afinal, para ele todos os valores considerados divinos não tem validade e, portanto, não há garantia mínima de compromissos mútuos. Como valores tais como a solidariedade, o amor, a justiça, o respeito ao próximo, a compaixão, dentre outros, do ponto de vista do crente, se fundamentam na divindade, a desconfiança em relação ao ateu como alguém indiferente, instrumental e sem compromisso com o próximo e com o bem comum são inevitáveis. Além disso, o ateísmo anula os parâmetros diante dos quais parece ser possível avaliar o caráter humanista ou não de uma ação, de modo que cada qual é abandonado a si mesmo e não existem mais critérios para distinguir o certo do errado. Sartre usa as seguintes palavras para descrever tal compreensão: “[...] suprimindo os mandamentos de Deus e os valores inscritos na eternidade, resta apenas a pura gratuidade; cada qual pode fazer o que quiser, sendo incapaz, a partir de seu ponto de vista, de condenar os pontos de vista e os atos alheios" (SARTRE, s/d, p. 2).

\begin{tabular}{|c|c|c|c|c|}
\hline Qevista Dialectus & Ano 2 & n. 4 & Janeiro-Junho 2014 & p. $127-149$ \\
\hline
\end{tabular}


Em suma: Deus representa o bem, que são os valores que nos possibilitam a vida, e não deixam que o mal, o egoísmo, a opressão e a dominação tenham a última palavra na luta de todos contra todos. Nesta perspectiva, quem nega Deus nega a própria humanidade. Sem Deus não passaríamos de animais egoístas.

Outro fator que torna o ateísmo uma hipótese extremamente sofrível para muitos é o fato de que com ele se nega também a possibilidade de uma vida pós-morte. Crença esta que ameniza muito o sofrimento causado pela perda de alguém, tornando a algo um pouco mais suportável. Sem esta crença, a esperança de um reencontro com pessoas queridas que já faleceram é negada, além de que implica a afirmação de que os sofrimentos e mesmo injustiças sofridas neste mundo não serão recompensadas: as injustiças deste mundo, portanto, nunca seriam desfeitas.

Por estes e outros motivos, a simples negação de Deus, sem mediações, certamente está inevitavelmente fadada ao fracasso, pois representa a negação daquilo que alguém religioso julga legitimamente como os valores mais importante em sua vida. Ao negar Deus, nega-se algo muito caro para as pessoas, os seus "desejos mais íntimos, os segredos de amor" (FEUERBACH, 1988, p. 56). A religião, além disso, conforme revela sua etimologia (re-ligio), empresta às pessoas uma compressão mais ampla/conjunta de sua vida, de modo que consigam, de alguma forma, orientar-se e construir um sentido próprio instituindo, assim, uma instância crítica capaz de fortalecer a sua identidade e, por conseguinte, sua capacidade de afirmação individual, de desenvolvimento de percepções coletivas e, assim, de resistência aos apelos heterônomos. A simples contraposição do ponto de vista do ateísmo à crença em Deus, portanto, representa uma violência contra o que geralmente há de mais sagrado/importante para o crente, representa uma insensibilidade para com aquilo que empresta sentido à vida humana e, em muitos momentos, forças para lutar pela vida e até mesmo por justiça. Não por acaso (e certamente por vezes com razão) que o crente identifica facilmente no ateu alguém presunçoso que se pretende superior a ele, uma vez que esse supostamente se pretende, inclusive, acima dos próprios valores divinos, senão do próprio Deus.

Por mais que uma postura religiosa possa ser questionada, no nosso modo de ver, seu potencial não pode ser ignorado. Pois, embora isto nem sempre seja assim, muitas pessoas, depois de perderem a referência da religião, não conseguem desenvolver outra referência coletiva ou humana de conduta, de modo que, de fato, o seu agir passa a ser instrumental e sem escrúpulos, tanto em relação aos outros quanto à

\begin{tabular}{|c|c|c|c|c|}
\hline Qevista Dialectus & Ano 2 & n. 4 & Janeiro-Junho 2014 & p. $127-149$ \\
\hline
\end{tabular}


natureza. Além disso, a perda das referências religiosas (lembremo-nos da expressão “Deus está morto. E agora?” de Nietzsche (2001, § 25) torna as pessoas muito mais vulneráveis a apelos idolátricos os mais diversos, como é o caso do fetiche do mercado e do consumismo. É como se existisse uma dimensão [a religiosa] que de uma ou de outra forma as pessoas buscam satisfazer. Neste sentido, por exemplo, e apesar de que muitas propostas religiosas da atualidade busquem adequar suas orientações com a sociedade do consumo, a submissão incondicional a esta e aos seus valores certamente contradiz uma instância que originalmente se pretendia crítica nas religiões: o perigo da adoração de falsos deuses, o fetichismo. Conforme a expressão cristã: não se pode adorar a Deus e ao dinheiro simultaneamente. Muitas vezes, o suposto ateísmo, por isso, não passa da transferência idolátrica a outros mecanismo ou instâncias. Assim, por exemplo, a adoração do Capital como Deus (SUNG, 1988) e a idolatria do mercado (fetiche) (ASSMANN \& HINKELAMMERT, 1989) encontram resistência como estruturas fetichistas diante de muitas concepções religiosas.

Mesmo que, segundo um ponto de vista ateu, Deus nada signifique, será que Nietzsche não tinha razão ao afirmar que "É melhor crer no nada do que nada crer"? Afinal a crença ainda revela alguma vontade de viver, não é niilista/indiferente. Mesmo que mínima, a religião parece oferecer a possibilidade de construção de um sentido na vida e, por isso, de inserção no mundo, portanto, de contraposição à indiferença. Na perspectiva aqui apontada é muito provável que a religião possa ser indicada como aquela dentre as dimensões humanas que mais contribui para uma perspectiva humanista. Ou seja, podemos afirmar, que, ao menos sob alguns aspectos, a religião é um humanismo!

\section{Ateísmo como afirmação do humanismo}

A afirmação de que o teísmo é um humanismo parece ser facilmente falseado na medida em que se aponta para o fato de que as instituições religiosas, embora se digam preocupadas com o bem estar espiritual são, muitas vezes, vistas "de mãos dadas" com estruturas de opressão e exploração. Inegavelmente a religião historicamente tem se prestado a legitimar e, assim, manter intocadas ou mesmo instaurar estruturas de desigualdade, poder e opressão. Lembremos, para tanto, apenas das estruturas sociais medievais, o massacre do povo ameríndio nas Américas pelas espadas em forma de cruz, ou a aceitação pacífica de muitas situações opressoras ainda hoje em nome de um

\begin{tabular}{|c|c|c|c|c|}
\hline Qevista Dialectus & Ano 2 & n. 4 & Janeiro-Junho 2014 & p. $127-149$ \\
\hline
\end{tabular}


“Deus quer assim!"”. Ou, e isto talvez seja um dos principais motivos da desconfiança em relação ao crente, a explícita contradição entre aquilo que se prega/se diz "vivenciar" na esfera religiosa/na igreja e aquilo que se vive no cotidiano. A religião, onde se cultuam valores como o amor ao próximo, a solidariedade, a igualdade, a justiça, dentre outros, parece antes um espaço para "aliviar a consciência" daqueles que protagonizam relações e estruturas sociais desumanizadoras. Assim se torna possível continuar mantendo uma vida em que estes mesmos valores nada significam (aparentemente sem contradição). Do mesmo modo, os oprimidos em nome desta esfera religiosa abstraem das verdadeiras origens sociais de seus sofrimentos, aceitando-os resignadamente. A religião passa assim, a tornar-se um entrave para a humanização, ela até mesmo inviabiliza a luta pela libertação por parte dos oprimidos, uma vez que estes projetam toda a sua esperança de uma vida e um mundo melhor/justo no além, deixando intocável o aquém-desumanizador. A crença numa vida pós-morte só encontra tanta aceitação pelo fato de as pessoas não poderem ter uma vida digna aqui e agora. A projeção para o pós-morte, no entanto, parece adquirir aqui uma função ideológica: evitar que as pessoas se engajem de fato por uma vida digna, facilitando a aceitação passiva de injustiças e sacrifícios.

Esta desconfiança crítica em relação à religião e a sua função social conservadora foi especial e explicitamente tematizada no contexto histórico do iluminismo, na medida em que se desenvolveu uma crença na razão como um elemento humano emancipatório, presente em todos os seres humanos. A razão esclarecedora passou, assim, a se afirmar como um antídoto da suposta "escuridão" religiosa. Em vez de crença o convencimento. Em vez de dogmas, argumentos. Em vez da justificação transcendente das relações sociais, a sua explicitação histórica, o evidenciamento das relações sociais de opressão e a afirmação da possibilidade e necessidade de sua superação. Em vez de uma história em forma de teodiceia, a história humana construída por homens e mulheres “de carne e osso". Em vez de adiar uma vida humana digna para uma possível outra vida, a luta para construção de um mundo onde a completude da vida possa ser experimentada já agora.

Afirmações como as de Freud (1978), de que a religião não passaria de um dos artifícios humanos criados para suportar o peso exigido pela civilização e que, não passaria de uma forma intimista de desperdício de energia que ademais, (quando corretamente sublimada para o trabalho, as ciências e as artes) poderia contribuir para o crescimento e fortalecimentos da civilização, expressam de forma exemplar esta

\begin{tabular}{|c|c|c|c|c|}
\hline Qevista Dialectus & Ano 2 & n. 4 & Janeiro-Junho 2014 & p. $127-149$ \\
\hline
\end{tabular}


posição. O futuro da ilusão religiosa (baseada inclusive na confusão entre inconsciente humano e divindade) dependeria da capacidade dos seres humanos fazerem uso de sua própria capacidade crítica a fim de se libertarem da mesma. Esta capacidade crítica estava sendo enfatizada, no mesmo período histórico, também por Nietzsche (1998) que lança suspeitas radicais aos valores que, por meio da religião, se apresentavam como transcendentes e eternos. A genealogia da moral é, na verdade, também uma historicização e antropologização da religião. A desmistificação das religiões certamente chama atenção para as origens sociais daquilo que se apresentava como divino e, por isso, inquestionável. O "Deus está morto, e agora?" de Nietzsche (2001, § 125), certamente indica para a incontornável necessidade de os seres humanos tomarem a história em suas próprias mãos em vez de a confiarem no além. De se entregarem à vontade de viver/potência em vez de se pautarem pela resignação ${ }^{2}$ e pela fraqueza.

Talvez uma das argumentações mais duras contra a religião e em favor do humanismo tenha sido desenvolvida por Ludwig A. Feuerbach. Sempre é bom lembrar que este autor desenvolveu a sua crítica na Alemanha, num contexto em que a crítica à forma política vigente á época parecia impossível por estar blindada por argumentos e pressupostos religiosos. A crítica à religião era, em grande medida, a crítica à estrutura de legitimação de uma ordem social considerada atrasada, retrógrada e injusta à época. Feuerbach desenvolveu o que se poderia chamar de ateísmo antropológico, uma vez que buscou mostrar que aquilo que era atribuído a Deus não passava de atributos humanos, a humanidade, no entanto, considerada do ponto de vista da sua espécie e não apenas do indivíduo. Assim, segundo Feuerbach (1988, p. 64), ao contrário do que de modo geral é atribuído ao ateísmo no sentido de que este seria a negação dos predicados divinos (como o amor, a solidariedade, a capacidade de criação, de conhecimento infinito, justiça, etc.), o ateísmo implicaria apenas a negação do sujeito ilusório destes predicados. Feuerbach entende demonstrar que todos os predicados que geralmente são atribuídos a Deus não passam de predicados da espécie humana como gênero (cf. SCHÜTZ, 2001, p. 17ss). A ilusão de que existiria objetivamente um ser (que não a humanidade) portador destes predicados gera, segundo este autor, um estranhamento da humanidade em relação a si própria, uma vez que exterioriza/aliena suas próprias

\footnotetext{
${ }^{2}$ Adorno (2010, p. 258) crítica Nietzsche do seguinte modo: "Nietzsche desconheceu que a assim chamada moral dos escravos, que ele critica, é, na verdade, sempre a moral dos senhores, a saber, a moralidade imposta aos oprimidos pela dominação. Se a sua crítica tivesse sido tão consistente como deveria, e não é [...] então essa crítica haveria de se voltar contra as condições que determinam os seres humanos e fazem deles, e de cada um de nós, o que somos". (Tradução nossa).
}

\begin{tabular}{|l|l|l|l|l|}
\hline Qevista Dialectus & Ano 2 & n. 4 & Janeiro-Junho 2014 & p. 127-149 \\
\hline
\end{tabular}


propriedades e passa, ilusoriamente, a atribuí-las a um ser independente dele. Retomar e reabilitar estas propriedades humanas/antropológicas seria, portanto, condição fundamental para o desenvolvimento do humanismo. Como, no entanto, tudo o que é projetado/objetivado em Deus não passa de características/propriedades humanas, a religião é a realização indireta daquilo que poderia ser considerado essencialmente humano. Só por ser "humano, demasiadamente humano", é que algo pode vir a ser considerado divino. No entanto, na medida em que esta "essência genérica" da humanidade não é reconhecida como tal, permanecendo projetada em um ser estranho, ela acaba atravancando a efetiva apropriação e desenvolvimento das potencialidades humanas. Em vez de servir à humanidade, o ser religioso passa a venerar e fetichizar uma criatura sua: o criador passa a venerar a sua própria criatura. Ao evidenciar os fundamentos humanos e antropológicos da religião, Feuerbach, mesmo que não explicitamente, colocou sob suspeita todas as estruturas sociais baseadas nas supostas verdades religiosas da época. Estas "verdades" eram defendidas pela teologia como dogmas inquestionáveis. Assim, a redução antropológica da religião realizada por Feuerbach permitiu desmascarar a teologia como uma antropologia disfarçada. Segundo nosso autor, o que importa é desvendar os fundamentos sociais e antropológicos da teologia, evidenciando seu conteúdo e objetivos ocultos.

$\mathrm{Na}$ perspectiva até aqui apontada, não parece difícil perceber que é preciso superar a religião para, enfim, pôr o ser humano como gênero no centro de qualquer perspectiva humanista. O ateísmo é, pois, a condição de possibilidade do humanismo. Pois enquanto for necessária a justificação divina como uma "desculpa" para a realização de ações humanistas é porque ainda não houve um convencimento profundo em favor do mesmo. Os valores humanistas, em vez de serem buscados na religião, deveriam, primeiramente, ser libertos das amarras e significações estreitas a que foram conduzidos no contexto religioso. Assim, por exemplo, muitas pessoas ao buscarem a religião, de fato estão buscando espaços de interação e convivência coletivocomunitária que não encontram em outros espaços. A vivência em comunidade, que, certamente, não é algo exclusivo das religiões, teria, portanto, de ser liberta destas.

Além disso, o fato de existirem diversas religiões, baseadas nas culturas de cada povo, inviabiliza a religião como horizonte comum de normas sociais, morais e éticas. Segundo o próprio Feuerbach, uma vez que Deus é antes a imagem e semelhança de cada povo, a religião revela justamente as diferenças e especificidades de cada povo ou mesmo indivíduo. Num mundo como o nosso que exige regras de convivência ética

\begin{tabular}{|c|c|c|c|c|}
\hline Qevista Dialectus & Ano 2 & n. 4 & Janeiro-Junho 2014 & p. $127-149$ \\
\hline
\end{tabular}


globais, a religião, portanto, se torna insuficiente como recurso último para justificar e legitimar o agir. O recurso à religião para o fortalecimento da ética, portanto, revela-se uma falácia, quando não um ensaio ideológico. Poderíamos dizer que, também isso, é uma prova de que a pretensão de afirmação ou superioridade religiosa de um povo sobre outro nada mais significa que a tentativa de imposição do seu modo de vida específico sobre os outros. Talvez por isso as religiões tenham estado ao lado e mesmo sido causas de grandes conflitos e mesmo de massacres humanos terríveis. O pensamento religioso, por tender fortemente para a afirmação dogmática de verdades, ou seja, não permitindo mais a manifestação e, por vezes, até mesmo eliminando fisicamente o diverso a ele, tende, portanto, a ser anti-humanista. Além disso, nem mesmo os protagonistas religiosos podem dizer-se humanistas, uma vez que supostamente não agem por eles mesmos, mas sim em nome de um suposto Deus que estaria acima deles. A autonomia e a história humana, no fundo, para eles, não passam de teodiceia. Evidentemente que a religião, neste sentido, se torna facilmente um poderoso instrumento ideológico, afinal, aquele grupo social ou mesmo indivíduo que consiga convencer os demais de que ele é o portador da vontade divina pode se permitir o exercício do poder de mando e obediência sob a aparência e bênção da vontade divina. Não é por acaso que a instrumentalização da religião, especialmente na sua forma institucional, tem sido alvo de disputas tão acirradas. O que está em questão, no fundo, são concepções de sociedade, de mundo e, não por último, estruturas de dominação e opressão.

Portanto, para falar com Sartre $(\mathrm{s} / \mathrm{d})$ a recuperação da responsabilidade e liberdade existencial individual numa perspectiva humanista precisa libertar-se das amarras religiosas que aprisionam e condenam a mesma ao imobilismo. No nosso modo de ver, no entanto, o desafio é também pensar/buscar a recuperação da liberdade para além da esfera individual, na perspectiva de que, [à contrapelo do tendencial sentimento de impotência e indiferença social/política], se possam visualizar possibilidades de engajamento e superação de estruturas opressoras e desumanizadoras. Ou seja, da possibilidade de se conceber e exercitar uma práxis social coletiva (que, no entanto, não anule a individualidade) que permita visualizar perspectivas que ultrapassem a mera felicidade e liberdade individual.

Um humanismo que de fato pretenda se afirmar sem recorrer à religião, teria de, necessariamente levar em consideração dimensões coletivas e sociais, embora as dimensões individuais também não devessem ser desprezadas. E por quê? Simplesmente pelo fato de as próprias religiões nos terem revelado (embora de forma

\begin{tabular}{|c|c|c|c|c|}
\hline Qevista Dialectus & Ano 2 & n. 4 & Janeiro-Junho 2014 & p. $127-149$ \\
\hline
\end{tabular}


indireta) que o ser humano busca, além dos seus desejos e sonhos individuais, algo para além desta individualidade, ele busca participar, a partir da sua especificidade individual, daquilo que o faz sentir um integrante da humanidade.

Karl Marx foi, talvez, quem absorveu e desenvolveu esta crítica de forma mais radical, tirando dela, inclusive, consequências sociais inéditas. Como, no entanto, Marx já havia aprendido de Feuerbach que a religião é uma espécie de "suspiro da criatura oprimida" considerava um equivoco a eliminação/supressão direta da religião, assim como sua superação por um simples ato de consciência. Ora, se a religião é, de fato, uma espécie de projeção daquilo que os indivíduos como seres genéricos (que Marx passa a denominar de "seres sociais") não conseguem efetivar e vivenciar no seu cotidiano, não é possível que este "suspiro" se torne desnecessário sem a superação e/ou supressão daquelas condições sociais e materiais que a tornam necessária. Portanto, já temos aí uma consequência tirada por Marx da leitura de Feuerbach que faz com que não se contraponha diretamente à religião ${ }^{3}$. A sua afirmação de que a religião é o "ópio do povo" aponta, no nosso modo de ver, justamente para isso: não basta eliminar o ópio, é preciso entender e superar as condições sociais que tornam o ópio da religião algo necessário para poder suportar a vida, tanto individual quanto socialmente falando. Nas palavras de Marx (1964, p. 78): “O apelo para que abandonem as ilusões a respeito da sua condição é o apelo para abandonarem uma condição que precisa de ilusões". Nesse sentido, a crítica à religião, realizada por Feuerbach, serve como um modelo crítico cujas consequências precisam ser pensadas até o fim. É neste sentido que Marx passa a buscar os fundamentos sociais e econômicos a serem superados. Mesmo assim, a crítica à religião permanece um modelo crítico constante: "A crítica da religião é o pressuposto de toda a crítica" (Idem, p. 77). Ou seja, a estrutura da crítica á religião indica para além da sua especificidade: para um horizonte mais amplo em que está inserida. Marx considerava, por exemplo, que na sua época um dos grandes motivos das mazelas sociais e misérias humanas era o "sistema da propriedade privada", sugerindo, assim, a necessidade de sua superação. Para Marx também seria possível estabelecer um paralelo direto entre superação da religião e a superação deste sistema: “[...] assim como o ateísmo enquanto eliminação de Deus constitui a emergência do humanismo teórico [...] o ateísmo é o humanismo mediatizado consigo por meio da eliminação da religião, ao passo que o comunismo constitui o humanismo obtido através da abolição da

\footnotetext{
3 Aí o equivoco de sistemas políticos que pretendem (ao contrário da perspectiva marxiana) eliminar/proibir a religião sem superar as condições que as tornam possíveis/necessárias.
}

\begin{tabular}{|l|l|l|l|l|}
\hline Qepista 2 ialectus & Ano 2 & n. 4 & Janeiro-Junho 2014 & p. 127-149 \\
\hline
\end{tabular}


propriedade privada" (Ibidem, p. 256). Ou seja, Marx aponta para uma perspectiva de compreensão de humanismo que teria de superar um humanismo puramente teórico. Como veremos no próximo item, com isso Marx aponta para uma perspectiva de humanismo que ultrapassa uma perspectiva puramente iluminista, que acredita poder substituir a religião por estruturas racionais. A perspectiva marxiana, no nosso modo de ver, indica para a necessidade da práxis social que considera o ser humano em sua integridade e que considera as questões de origem religiosa de suma importância, pois elas indicam diretamente para as dimensões individuais e/ou sociais reprimidas por um determinado sistema social, político ou econômico. Não por acaso a análise em torno do potencial da crítica à religião é ampliada de tal forma em Marx que pôde ser concluída com "[...] o imperativo categórico de derrubar todas as condições em que o homem surge como um ser humilhado, escravizado, abandonado, desprezível” (Ibidem, p. 86).

Depois das reflexões feitas por Nietsche, Marx e Freud apontando para os limites e vulnerabilidades ideológicas, morais e psicológicas da razão, a religião não pode mais ser tomada como um fato ingênuo e despretensioso a ser contraposto à razão. Por mais que seu fenômeno nos pareça algo natural, a sua manifestação específica nas diversas culturas, religiões, indivíduos e sociedades é sempre também um construto social e, nesse sentido, é também sempre resultado desta realidade. Inúmeras vezes, valores social e individualmente importantes são "sequestrados" e instrumentalizados religiosamente. Não são, nesse sentido, uma pura ilusão, mas sim uma ilusão necessária que contribui para a legitimação de uma determinada condição social: enquanto certos valores/dimensões humanas permanecem no além, eles não se tornam referências críticas no aquém. O desafio do ponto de vista de um ateísmo alargado para questões sociais (na forma como sugerido por Marx), portanto, não é o de negar esses valores, mas sim torná-los valores do "reino da terra" em vez de mantê-los encastelados no “reino dos céus". Isto, no entanto, não pode ser feito por decreto nem por um puro ato de consciência (como talvez ainda acreditava Feuerbach): exige a práxis. Ao que parece, uma questão/critério orientador para Marx era o fortalecimento do humanismo. A simples negação (inviabilizar o "suspiro da criatura oprimida") que, à primeira vista e numa perspectiva ateísta vulgar talvez possa parecer algo possível, na perspectiva apontada por Marx teria de ser antes compreendida como uma postura anti-humanista.

\section{Religião e ateísmo como possibilidades de enriquecimento do humanismo}

\begin{tabular}{|l|l|l|l|l|}
\hline Qepista Dialectus & Ano 2 & n. 4 & Janeiro-Junho 2014 & p. 127-149 \\
\hline
\end{tabular}


Pelo que foi tematizado até agora parece que permanecemos em uma posição antinômica e uma perspectiva de superação da mesma não parece possível à primeira vista: o crente se afirma portador de uma perspectiva humanista tanto quanto o ateu. No entanto, o critério de uma perspectiva humanista no sentido que a buscamos deflagrar com apoio de Marx, já nos parece indicar para a possibilidade de constituição de um horizonte onde - apesar de sua aparente contradição - estas duas posições possam ser compreendidas de forma complementar e, talvez, até mesmo fortalecer-se entre si no que diz respeito à possibilidade de contribuição para o humanismo. A seguir, destacaremos algumas questões que indicam para a possibilidade de se buscar a superação desta situação anacrônica que inviabiliza um diálogo produtivo entre ateus e crentes numa perspectiva humanista. Evidentemente, pretendemos apenas contribuir com algumas perspectivas e com a explicitação de questões, cientes de que vários outros aspectos não serão tematizados nesse momento.

Uma primeira questão se relaciona com a própria compreensão de humanismo. Não ignoramos que talvez seja possível afirmar que algumas das formas políticas mais terríveis (e por isso não humanistas) da história da humanidade tenham sido sistemas que se afirmavam portadores dos valores da humanidade e que sua luta era uma luta a favor do humanismo e contra os inimigos destes (cf. HINKELLAMERT, 1995). Mesmo que usada apenas como um recurso legitimador, já se fez (e muito provavelmente ainda se faz) muitas barbáries em nome da "Humanidade". Muitas guerras na atualidade se dão, mesmo que mais especificamente em torno da suposta defesa de direitos humanos, sob o pretexto da defesa da humanidade. Agir em nome da humanidade certamente muitas vezes é um artifício usado para buscar afirmar a superioridade em relação a outros. Basta lembrar que tanto o fascismo quanto o stalinismo se diziam redentores da humanidade. E também o sistema produtor de mercadorias requer enormes sacrifícios ambientais e sociais em nome de uma suposta melhoria das condições de vida da humanidade (Idem). O jurista e pensador político Carl Schmitt (1984, p.51) chega a afirmar que "Quem diz humanidade quer enganar". Além disso, a referência à humanidade é, por vezes, utilizada de modo indireto quando, por exemplo, algo como a defesa da liberdade [considerada um característica fundamental da humanidade] se torna uma referência de legitimação política ou mesmo de ofensivas violentas. Em nome da liberdade e da humanidade certamente muitos sacrifícios já foram feitos e supostamente justificados, e é importante que tenhamos isto sempre criticamente presente. Mesmo assim, uma questão que nos parece de suma importância neste contexto é: por que a

\begin{tabular}{|c|c|c|c|c|}
\hline Qevista Dialectus & Ano 2 & n. 4 & Janeiro-Junho 2014 & p. $127-149$ \\
\hline
\end{tabular}


ideia de humanidade e seus correlatos exercem tamanha atração, a ponto de poderem ser instrumentalizados pelos mais diversos sistemas políticos e econômicos? Provavelmente este é um debate inesgotável, uma vez que o que nos caracteriza historicamente como seres humanos certamente deve ser a manifestação de algumas dimensões ínfimas de nossas potencialidades e muito provavelmente ainda estamos nos constituindo e emergindo como uma dimensão da própria natureza ${ }^{4}$. Algo, no entanto, parecer ser prudentemente evitável: a definição de uma essência que pudesse ser afirmada para além da historicidade concreta dos seres humanos. Dizer-se defensor do humanismo, portanto, não pode ser confundido com a defesa incondicional de uma ou outra suposta essência humana, isto seria fetichismo. O humanismo implica, antes, a consciência radical da historicidade humana - não determinada a priori, mas construída individual e coletivamente. Em outras palavras: a máxima sartreana de que no ser humano a existência precede a essência, no nosso modo de ver, não se restringe ao horizonte individual, abrangendo também a coletividade social. Instigar o humanismo implicaria, portanto, a constituição progressiva de condições para que todos os seres humanos, individual e coletivamente, possam autodesenvolver as suas potencialidades de modo pleno e mesmo ir desenvolvendo novas. Isso não implica a afirmação/primazia do sujeito $^{5}$, que em Sartre ainda parece preponderante, em relação ao mundo. Pelo contrário, o humanismo parece incompatível com uma postura onde não há mais a constante abertura da consciência e da práxis para com as novidades, para com o objeto/mundo. A compreensão de que somos seres condicionados, mas não determinados, e que nas sociedades humanas existe uma primazia da historicidade humana (embora esta seja apenas uma das dimensões da própria natureza) parece fortalecer uma postura que pode funcionar como um antídoto contra premissas ideológicas que eventualmente requeiram sacrifícios em vistas de algum ideal/fetiche externo [mesmo que este se apresente como sinônimo ou portador da humanidade]. Também é importante dizer que humanismo não deve ser tomado como sinônimo de antropocentrismo. A possibilidade de que a humanidade se desenvolva adequada e satisfatoriamente não nos parece compatível com a destruição do meio ambiente e de outros seres. Um vestígio disso já se revela quando dizemos que "humanizamos" um

\footnotetext{
${ }^{4}$ Compare "A emergência do humano em Marx”, de Schorn \& Schütz (2013).

5 A este respeito ver Schütz (2012), especificamente o item "Primazia do objeto e Dialética Negativa: filosofia enquanto crítica".
}

\begin{tabular}{|l|l|l|l|l|}
\hline Qepista Dialectus & Ano 2 & n. 4 & Janeiro-Junho 2014 & p. 127-149 \\
\hline
\end{tabular}


ambiente ao introduzir nele uma planta, ou de que os jardins e parques humanizam as casas e cidades.

Uma segunda questão, que não nos deixa satisfeitos com uma simples contraposição antinômica entre crença e religião, pode ser tematizada exemplarmente através da abordagem crítica do próprio conceito de filosofia e sua função. Acreditamos que a simples contraposição entre razão/filosofia à religião [geralmente afirmando a superioridade de uma sobre outra] é insuficiente. Esta postura nos torna incapazes de perceber os limites da crítica à religião feita a partir da tradição ilustrada e tampouco a fortalece contra a instrumentalização ideológica.

Como se sabe, a capacidade de se espantar/admirar com o mundo para, a partir daí, pensar de forma inédita, é uma das condições da filosofar desde o seu surgimento. No entanto, por muitas vezes na história da filosofia, este impulso original foi enfraquecido frente à racionalização/esquematização demasiada. Como toda a racionalização, pelo fato de que inevitavelmente se apoia na linguagem e nos conceitos, reprime alguns de seus próprios pressupostos não racionais [“origem mítica do logos" (TÜRCKE, 1995)], de modo que, muitas vezes, os pensamentos, mesmo que se pretendam profundamente críticos ocultam seus pressupostos. Por isso, no nosso modo de ver, uma filosofia com pretensões críticas, não pode aceitar o pressuposto de que tudo que se contraponha à razão deva ser a priori considerado de menor importância ou mesmo falso, como muitas vezes é o caso na contraposição entre razão à religião. Do mesmo modo, do que foi dito pode se concluir que a contradição entre conceitos (como entre razão e religião) talvez não seja a única possibilidade de contradições. Acontece, conforme apreendemos de Adorno (2009, p. 54) que os conceitos, podem conter contradições neles próprios, pois possuem uma "historicidade interna". Assim, por exemplo, dentro do próprio conceito de religião ou mesmo de razão podem existir dimensões que se coadunem com o humanismo e outras não. Ou seja, a história dos conceitos pode ter nos levado a perceber apenas algumas dimensões dos mesmos, sem que suas contradições implícitas possam ser visualizadas à primeira vista. Um dos desafios da filosofia poderia ser justamente o de procurar rejuvenescer/reavivar os conceitos na medida em que evidencia as contradições que lhes são inerentes/latentes. Ora, isto dito, não se pode mais aceitar que a verdade ${ }^{6}$ toda esteja em um conceito em contraposição a outro totalmente falso, uma vez cada conceito precisa dos outros para

\footnotetext{
${ }^{6}$ Orientamos nossa noção de verdade por aquela sugerida por Adorno. A respeito ver Schütz (2013).
}

\begin{tabular}{|l|l|l|l|l|}
\hline Qevista Dialectus & Ano 2 & n. 4 & Janeiro-Junho 2014 & p. 127-149 \\
\hline
\end{tabular}


ser compreendido em seu contexto e conexões. Portanto, não se trata apenas de estabelecer a contradição entre religião e razão a fim de declarar uma como verdadeira e outra como falsas, mas de buscar as contradições contidas no próprio conceito de religião e razão. Parece-nos que assim abrimos a possibilidade de compreensão de questões comuns que ultrapassam a armadilha criada pela simples oposição de um conceito a outro e de perceber dimensões complementares numa perspectiva emancipatória.

Deste modo alcançamos uma nova posição, pois se a filosofia ou a razão que, em grade medida, é tomada pelo ateu como um instrumento autônomo a ser contraposto à religião, não puder mais ser tomada isoladamente, se de fato há algo anterior à razão e ao pensamento sem o qual nossos pensamentos e conceitos não seriam o que são, então torna-se difícil estabelecer a razão como o único tribunal capaz de declarar o que é e o que não é verdadeiro. Também a religião não deveria mais abdicar da análise crítica de suas práticas a fim de evitar ao sua instrumentalização ideológica. Porque a religião não poderia, por vezes, ser inclusive aquela instância instigadora do pensamento, da razão e da filosofia? Porque a filosofia/razão não poderia contribuir para a liberação dos potenciais críticos da religião? No nosso modo de ver esta perspectiva parece perfeitamente possível. Nada impede que a filosofia aconteça a partir de questões suscitadas pela religião nem que esta fortaleça seus impulsos libertários pela filosofia. Se é das contradições latentes nos próprios conceitos que a filosofia se nutre e desde onde ela se constitui como tal, então ela pode instigar uma postura crítica em relação ao mundo na religião e a religião pode contribuir para evitar o atrofiamento da filosofia em algo puramente racional $^{7}$.

$\mathrm{Na}$ perspectiva que aqui tentando apontar, simplesmente negar a religião como falsa consciência não satisfaz a realidade e seria uma posição equivocada/desleal desqualificá-la como possível instância crítica. A religião é constitutiva do mundo humano e por meio dela acrescentam-se dimensões humanas inéditas ao gênero humano. Como tal ela não pode ser menosprezada pela filosofia. Sua desconsideração tem caráter tão ideológico quanto a sua afirmação absoluta e dogmática. Se a primazia do objeto/mundo em relação ao sujeito é premissa básica de qualquer teoria que se

\footnotetext{
${ }^{7}$ Recorramos a T. Adorno (2009, p. 53): "Somente os conceitos podem realizar aquilo que o conceito impede. [...] O erro determinável de todo conceito obriga a que se evoque outros; é daí que emergem aquelas constelações para as quais unicamente passa alguma coisa de esperança contida no nome [...] $\mathrm{O}$ que ela critica nas palavras, sua pretensão de uma verdade imediata, é quase sempre a ideologia de uma identidade positiva, essente, entre a palavra e a coisa".
}

\begin{tabular}{|c|c|c|c|c|}
\hline Qevista Dialectus & Ano 2 & n. 4 & Janeiro-Junho 2014 & p. $127-149$ \\
\hline
\end{tabular}


queira crítica, então a religião, assim como a arte, não podem simplesmente ser consideradas formas de consciência humana menos importantes/significativas. A realidade não poder ser simplesmente enquadrada em conceitos prévios (Adorno) e ela também precisa vir até o pensamento (Marx), sob risco de incorrermos em idealismo.

Neste sentido, estamos convencidos de que seja possível que crentes se tornem humanistas, críticos e até comunistas. No Brasil, por exemplo, o pensamento crítico muito vezes se fortaleceu e mesmo se constituiu a partir daquelas experiências sociais oriundas da teologia da libertação que foram/são experiências de religiosidade e mística não atrofiadas em pura submissão, contribuindo, inclusive, para impulsionar processos emancipatórios $^{8}$. Portanto, a religião pode levar ao engajamento crítico, no sentido humanista apontado por Marx. Uma pergunta, que à primeira vista parece ser totalmente absurda do ponto de vista ateu, adquire sentido diante desta experiência específica: "Há na religião algo que pode levar ao comunismo humanista?"

Se, como admite até mesmo Feuerbach, a religião "revela os desejos mais íntimos" do ser humano, então, talvez seja possível mobilizar estes conteúdos numa perspectiva emancipatória. Como afirma Zamora (2008, p. 31), esta possibilidade se “centra sobretudo na dimensão de verdade dos potenciais críticos da religião. [...] seus momentos de protesto e resistência diante de uma imanência acabada" (Idem). Chegamos, assim, senão a demonstrar a complementariedade entre crença e religião ao menos, a apontar para a possibilidade de que isto possa ser imaginado e aconteça. Assim como alguém religioso pode ser tão ou mais humanista que o ateu o contrário também é válido. Ou seja, a filosofia/razão não necessariamente suspende a religião. Dizer que alguém é ateu também não significa automaticamente que ele seja mais ou menos humanista que o religioso. Fato é que a religião pode impulsionar e renovar a filosofia e, por isso, talvez também subsidiar e enriquecer o humanismo do ateu. Assim como o humanismo ateu pode vir a enriquecer temática e criticamente a religião.

A fim de fortalecermos a perspectiva aqui indicada apontaremos para algumas reflexões do filósofo Ernst Bloch tratadas em sua obra "Ateísmo no Cristianismo" (1977), especialmente no item "Da relação entre marxismo e religião". Esta obra tem por objetivo indicar uma perspectiva de aliança entre "religião e revolução", ou seja, entre religião e a perspectiva ateísta humanista, na forma como foi tematizada por Marx a partir de Feuerbach. Dentre os diversos temas abordados por Bloch nessa obra, nos

${ }^{8} \mathrm{O}$ elogio das experiências religiosas marcadas pela teologia da libertação numa perspectiva emancipatória foi muito bem tematizada por Löwy (2000; 2004).

\begin{tabular}{|l|l|l|l|l|}
\hline Qepista Dialectus & Ano 2 & n. 4 & Janeiro-Junho 2014 & p. 127-149 \\
\hline
\end{tabular}


interessam principalmente aqueles que, simultaneamente fornecem uma reserva crítica em relação às manifestações religiosas elas mesmas, mas também frente aos preconceitos oriundos de posições denominadas por ele de "ateísmo do marxismo vulgar" e "ateísmo burguês".

Segundo Bloch, de modo geral, de fato a religião surge diante da necessidade e/ou do sofrimento. No entanto, muitas vezes parece que "aqueles que vivem do rezar também estimulam o sofrimento" (Bloch, 1977, p. 87). Ou seja, a fim de manter uma dependência baseada em pressupostos religiosos, mantém-se as situações sociais que tornam as pessoas suscetíveis a apelos religiosos, de modo que, muitas vezes, os que se dizem preocupados com o bem estar espiritual são vistos associados ao poder que oprime e explora. Esta instrumentalização da religiosidade que leva à submissão e dominação, além de se fundar no medo dos oprimidos em relação aos opressores, se apoiaria também na crença por parte dos oprimidos de que os desejos podem ser "saciados desde cima". No entanto, apesar dessa constatação crítica, Bloch não aceita a redução da religião apenas a esta função. Sua convicção é de que a religião, especialmente no caso do cristianismo, foi degradada a esta função conservadora somente quanto foi "aprisionada" institucionalmente. "Historicamente a religião apenas se conectou com a sociedade de classes [...] na medida em que ela foi quase que equiparada com igreja" (Idem, p. 90) ${ }^{9}$. A crítica do marxismo vulgar, portanto, não distinguiria entre religião e sua manifestação institucional como igreja. O que se quer criticar é a função ideológica das igrejas, e acaba-se por condenar a própria religião. Ao não fazer esta distinção, o potencial crítico da religião passaria despercebido e a função ideológica da religião permaneceria intocável já que é "entregue" às forças conservadoras da sociedade. Ao não perceber que também a religião é um campo de disputa de mundos permeada por contradições o ateísmo vulgar perde a oportunidade de enriquecer o seu humanismo. Segundo Bloch, apesar da forte redução/instrumentalização institucional da religião ela não pode ser equiparada a esta dimensão. Historicamente, segundo o autor, sempre se mantiveram "formas sociais de crença anti-igreja de religião", seja como seitas ou como tendências, por mais que estas muitas vezes tenham permanecido inobserváveis e se desenvolvendo nos subterrâneos da oficialidade/institucionalidade. A religião como ideologia e ópio do povo seria criticável apenas na sua forma social mais poderosa: a igreja. A religião, no entanto, não

\footnotetext{
${ }^{9}$ Todas as citações desta obra de Bloch (1977) foram traduzidas por nós do original em língua alemã.
}

\begin{tabular}{|l|l|l|l|l|}
\hline Qevista Dialectus & Ano 2 & n. 4 & Janeiro-Junho 2014 & p. 127-149 \\
\hline
\end{tabular}


deveria ser reduzida aos "lamentos igrejeiros". Segundo Bloch, as suas "fontes jorram de algum outro lugar". E o desafio é fazer com estas próprias fontes ("protesto da criatura oprimida") possam se manifestar explicitamente de modo a se constituírem num impulso crítico contra a sociedade opressora.

Esta seria uma postura materialista, pois, em vez de simplesmente impor/contrapor um ideal externo à consciência religiosa (que seria a postura marcantemente elitista/presunçosa que Bloch chama de ateísmo burguês) que é sempre um idealismo (mesmo que disfarçado de materialismo) o desafio é tornar o que há de humano no fundamento religioso um impulso emancipatório. Marx jamais teria afirmado que não existe deus e nem que ele é "uma simples invenção dos padres". Em vez de ter incorrido nesta ingenuidade histórica, Marx teria, por causa da sua herança feuerbachiana, tido muito claro que "a religião não surge de uma trapaça (Betrug) mas sim de uma ilusão não transparente (undurchschaubare Ilusion)" (BLOCH, 1977, p. 89). Neste sentido, aquilo que é humano (e que já está revelado, embora de forma alienada, na religião) é o que impulsiona para o não religioso e o engajamento no mundo e não a imposição de ideais desde fora. Quando Bloch afirma que a filosofia é “ajudante da parteira" (revolução) que, portanto, apenas ajuda a parir aquilo do qual a realidade já está prenhe, se refere a esta posição materialista, que preza pela primazia do objeto. Ou seja, ela não pode protagonizar processos revolucionários impondo ideais desde fora, mas sim ajudando a fazer nascerem os potenciais já imantes/latentes na realidade. Com isso, o ateísmo burguês, [que pressupõe uma razão e um sujeito tornados autônomos "por decreto" e considerados previamente superiores à religião], é colocada sob suspeita, ou melhor, seu caráter idealista e, por isso, ideológico, é revelado. A utopia concreta não pode abdicar da poderosa voz latente no mundo e que se manifesta de forma privilegiada no fenômeno religioso.

Bloch considera que com o desenvolvimento de uma postura coerente com uma abordagem materialista da religião seja possível constituir um espaço de diálogo onde o crente não seja necessariamente ideologizado e o ateu não permaneça mais ensurdecido frente à religião. Na religião, tanto quanto no marxismo como uma postura atéia, existe a possibilidade e até mesmo a exigência de transcender o existente sem que para tal seja necessária a transcendência ("transcender sem transcendência"). Segundo Bloch, transcender é um elemento vital do marxismo - correspondente, em certa medida, aos arquétipos de liberdade da religião (Ibidem, p. 315). Inclusive, a transcendência sempre poderia ser levada até o limite da irreligiosidade, o que pode ser atestado no fato de que

\begin{tabular}{|c|c|c|c|c|}
\hline Qevista Dialectus & Ano 2 & n. 4 & Janeiro-Junho 2014 & p. $127-149$ \\
\hline
\end{tabular}


a mística não é algo necessariamente reacionário, podendo, inclusive, ser algo laico. $\mathrm{O}$ desafio é perceber os tesouros apreendidos no céu como propriedades humanas sem negar a religião ou declará-la de antemão uma manifestação humana inferior. Estas considerações de Bloch se situam no horizonte do que chama de "ontologia do aindanão-ser”, que pressupõe que o processo dialético-material da história é algo aberto e ainda não decidido, permeado por possibilidades de futuros latentes/imanentes na própria realidade. Assim, Bloch inclusive se contrapõe a uma visão estarrecida e mecânica do mundo que, segundo ele, muitas vezes orienta algumas posições supostamente marxistas desde onde se gesta um ateísmo vulgar.

Apenas a título de exemplificação do que Bloch (1977, p. 100) sugere nessa perspectiva, apontamos aqui para a sua afirmação de que a Bíblia, analisada desde esta perspectiva, poderia se tornar um livro revolucionário. Como? Pelo fato de toda a bíblia ser perpassada por uma narrativa (mesmo que esta tenha sido reprimida e ignorada pela religião institucionalizada) que conduz desde a terra da servidão (escravidão do Egito) para a terra da liberdade (reino dos homens). Na bíblia pulsaria uma esperança de completude humana, a partir do que se poderia afirmar que há uma "utopia de algo não religioso na religião". Portanto, existiria na bíblia uma utopia subterrânea que também intentaria, tal como Marx, superar todas as relações sociais onde o ser humano aparece como ser oprimido e desprezado.

\section{Considerações finais}

Com o que procuramos delinear acima acreditamos poder afirmar que tanto religião quanto o ateísmo podem contribuir para o fortalecimento de um humanismo crítico e histórico. Isso não nos exime da necessidade crítica frente à possível função ideológico-conservadora da religião, especialmente quando institucionalizada. Do mesmo modo o ateísmo vulgar tanto quanto o ateísmo burguês merecem ser criticados no que diz respeito ao seu caráter idealista e conservador. Mas se à filosofia cabe o desafio de trazer pela primeira vez para o conceito aquilo que permanecia préconceitual; se as contradições existem nos próprios conceitos e não apenas entre conceitos; se, do ponto de vista de uma teoria crítica, não se trata de descartar como não verdadeiro aquilo que não se coaduna previamente com a razão; se de fato, conforme Feuerbach, na religião "se revelam os desejos mais íntimos e secretos" dos seres humanos, então trazer para a esfera conceitual aquilo que se manifesta de modo não

\begin{tabular}{|c|c|c|c|c|}
\hline Qevista Dialectus & Ano 2 & n. 4 & Janeiro-Junho 2014 & p. $127-149$ \\
\hline
\end{tabular}


conceitual na religião pode se constituir uma tarefa emancipatória muito produtiva. Conforme Schelling (1985) a religião, assim como a arte, é precursora da filosofia, seus temas indicam para aquilo que está emergindo, que pode ser, mas ainda não é. Elas seriam, portanto, complementares em vez de contrapostas.

O ateísmo vulgar, portanto, se equivoca ao considerar a religião uma simples trapaça, embora muitas vezes ela seja instrumentalizada institucionalmente para tal. O ateísmo burguês também se equivoca ao simplesmente contrapor razão e religião e considerar a religião uma falsa consciência da realidade, outorgando a si própria o monopólio da verdade ${ }^{10}$. A simples desqualificação de todos os temas de origem religiosa na filosofia talvez seja parte de uma ideologia que a bloqueia e isola diante de algumas das questões mais importantes de sua época. A absolutização desta antinomia carrega, em ambas as extremidades, o pressuposto da existência de verdades absolutas, não historicamente mediadas: aparência socialmente necessária para a manutenção do status quo. É justamente esta absolutização, seja por qual das partes for, que afasta o ateu do diálogo com a religião e vice-versa, inviabilizando qualquer forma de aliança emancipatória.

Por fim, se, de fato, conforme indica Adorno (2009), para o desenvolvimento da filosofia crítica é muito mais importante aquilo que a primeira vista não se expõe (o não-idêntico), então esta precisa estar em constante diálogo com o que ela ainda não é, com aquilo que ainda não foi pensado. Ou seja, de modo semelhante à psicanálise, [em que, como se sabe, aquilo que está oculto é o que gera a doença e que, num processo de cura, necessariamente precisa ser tornado consciente e/ou re-significado, fazendo com que aquilo que não é previamente conhecido seja o alvo principal dos esforços terapêuticos e teóricos], a filosofia crítica também deveria centrar suas atenções no explicitar/trazer à tona aquilo que à primeira vista não se deixa tratar filosoficamente. $\mathrm{E}$ a religião, na atualidade, provavelmente é uma das fontes mais ricas de elementos nãoidênticos, embora estes muitas vezes estejam ideologicamente instrumentalizados. Talvez pudesse ser uma perspectiva bastante produtiva a investigação da hipótese de que na atualidade a religião se tornou uma espécie de refúgio do não-idêntico (onde aquilo que oprime a criatura oprimida pode se manifestar, mesmo que sem poder tornarse potência crítica) que poderia indicar pistas interessantes para o fortalecimento e

\footnotetext{
${ }^{10}$ Como já sabemos de Adorno (s/d, p. 127): "Não corresponde à filosofia fingir que pode tirar tudo limpidamente de si mesma. Muito ao contrário, isso forma parte das ilusões da filosofia, que ela mesma deve destruir".
}

\begin{tabular}{|l|l|l|l|l|}
\hline Qepista 2 ialectus & Ano 2 & n. 4 & Janeiro-Junho 2014 & p. 127-149 \\
\hline
\end{tabular}


renovação do pensamento crítico. De fato, talvez a religião tenha se tornado uma espécie de refúgio da não-identidade em meio a um mundo cada vez mais desencantado pela técnica e dominado por relações sociais administradas e secularizadas.

Recorrendo a um instrumental conceitual de Bloch (2006, p. 79; 1977, p. 350), nos é permitido afirmar que a religião pode contribuir sobremaneira com o marxismo na sua "corrente quente", no sentido de alimentá-la com "arquétipos humanizados", e impulsionando/fortalecendo o otimismo militante. Ela aponta para tendências e latências reais e, por isso, não pode ser ignorada por qualquer posição que não se restrinja à tentação idealista de impor ideais externos à realidade. Já a posição do humanismo ateu, ao radicalizar o caráter histórico e antropológico da humanidade, certamente, contribui para o fortalecimento crítico dos potenciais emancipatórias da religião subsidiando a sua "corrente fria" e contribuindo para imunizá-la contra o aparelhamento ideológico. Sem algum ingrediente deste ateísmo a religião certamente se torna muito mais vulnerável frente à instrumentalização ideológica. Para não se deixar confundir com instituições e artimanhas ideológica a religião não pode abdicar de seus fundamentos sociais e antropológicos. Talvez só assim ela possa evitar a concepção e adoração fetichista de falsos deuses.

Finalizemos com uma citação de Bloch (1977, p. 353):

O autêntico marxismo, portanto, leva a sério o autêntico cristianismo [...] se do ponto de vista cristão ainda se busca a emancipação dos humildes e sobrecarregados, se do ponto de vista marxista a profundidade do reino da liberdade é e continua sendo o conteúdo substancializador da consciência revolucionária, então a aliança entre revolução e cristianismo, que uma vez aconteceu nas guerras camponesas (Bauernkriegen), não terá sido a última desta vez vitória.

\section{Referências Bibliográficas}

ADORNO, T. A atualidade de filosofia. Tradução: Bruno Pucci, (s/d). Disponível em: http:// adorno.planetaclix.pt/tadorno3.htm. Acessado em: 11 jul. 2014.

Dialética negativa. Tradução: Marcos Antônio Casanova. Rio de Janeiro: Zahar, 2009.

. Probleme der Moralphilosophie. Frankfurt am Main: Suhrkamp, 2010.

Zur Lehre von der Geschichte und von der Freiheit. Frankfut am

Main: Suhrkamp, 2006.

\begin{tabular}{|l|l|l|l|l|}
\hline Qepista Dialectus & Ano 2 & n. 4 & Janeiro-Junho 2014 & p. 127-149 \\
\hline
\end{tabular}


ASSMANN, Hugo, HINCKELAMMERT. J. Franz. A idolatria do mercado. Ensaio sobre economia e teologia. São Paulo: Vozes, 1989.

BLOCH, Ernst. Atheismus im Christentum. Zur Religion des Exodus und des Reichs - Gasamtausgabe Band 14. Frankfurt am Main: Suhrkamp, 1977.

O Princípio Esperança, Volume I. Tradução de Nélio Schneider. Rio de Janeiro: EdUERJ: Contraponto, 2006.

FEUERBACH, Ludwig. A Essência do Cristianismo. Campinas: Papirus, 1988.

HINKELAMMERT, Franz. J. Sacrifícios humanos e sociedade ocidental. Lucifer e a Besta. São Paulo: Paulus, 1995.

FREUD, Sigmund. O futuro de uma ilusão (Coleção "Os Pensadores"- vol. Freud). Tradução de José Otávio de Aguiar Abreu. $2^{a}$ ed. São Paulo: Abril Cultural, São Paulo, 1978.

MARX, Karl. A Questão Judaica. In: Manuscritos EconómicoFilosóficos. Lisboa: Edições 70, 1964a.

Contribuição à crítica da Filosofia do Direito de Hegel (Introdução). In: Manuscritos Económico-Filosóficos. Lisboa: Edições 70, 1964.

NIETZSCHE, W. F. Genealogia da moral: uma Polêmica. Trad. Paulo César de Souza. São Paulo: Companhia das Letras, 1998.

A gaia ciência. São Paulo: Companhia das Letras, 2001.

LÖWY, Michael. A guerra dos deuses: Religião e política na América Latina. Petrópolis: Vozes-Clacso, 2000.

Marxismo e religião: ópio do povo? Disponível em http://bibliotecavirtual.clacso.org.ar/ar/libros/campus/marxispt/cap.11.doc. Acesso em 10 de julho de 2014.

SARTRE, Jean Paul. O Existencialismo é um humanismo. Tradução: Rita Correia Guedes, (s/d). Disponível em: http://pt.scribd.com/doc/7165346/Jean-Paul-Sartre-OExistencialismo-e-Um-Humanismo. Página visitada em 14.07.2014.

SCHELLING, Friedrich Wilhelm Joseph. Einleitung in die Philosophie der Offengahrung oder Begründung der positiven Philosophie. Berliner Vorlesungen (1942/43). In: Ausgewählte Schriften. Band 05. Frankfurt am Main: Suhrkamp, 1985

Grundlegung der positiven Philosophie. Münchener Vorlesung WS 1832/33 und SS 1833 (I. Teil). Torino: Botteg d'Erasimo: 1972

SCHÜTZ, Rosalvo. Religião e capitalismo: uma reflexão a partir de Feuerbach e Marx. Porto Alegre: EDIPUCRS. Coleção Filosofia 126, 2001.

\begin{tabular}{|l|l|l|l|l|}
\hline Qenista 2 ialectus & Ano 2 & n. 4 & Janeiro-Junho 2014 & p. 127-149 \\
\hline
\end{tabular}


Refúgio da liberdade. Sobre a concepção de filosofia de T. Adorno. In: Revista Veritas, Porto Alegre, v. 57, p. 32-52, 2012.

.; SCHORN, Remi. A emergência do humano em Marx. In: Princípios: revista de filosofia, Natal, v. 20, p. 99-124, 2013.

SCHMITT, Carl. El concepto de lo político/Teoría del partisano. Buenos Aires: Folios Ediciones, 1984.

2006.

Teologia Política. Trad. De E. Atoniuk. Belo Horizonte: Del Rey,

SUNG, Mo Sung. A idolatria do Capital e a morte dos pobres. Uma reflexão teológica a paratir da dívida externa. São Paulo: Paulinas, 1989.

TÜRCKE, Christoph. O nascimento mítico do logos. IN: DE BONI, Luiz Alberto (Org.). Finitude e transcendência. Petrópolis: Edipucrs/Vozes, 1995.

ZAMORA, José Antônio. Adorno e a Religião. In: ZAMORA, José Antônio; PUCCI, B.; MOREIRA, Alberto da Silva. Adorno: educação e religião. Goiânia: Editora da UCG, 2008. 